\title{
THE IRRIGATION INFLUENCE UNDER THE SOIL, MICROCLIMATE AND PLANTS IN MAIZE FROM CRIŞURILOR PLAIN
}

\author{
Cornel Domuța $^{1}$, Maria Şandor ${ }^{1}$, Vasile Bara ${ }^{1}$, Gheorghe Ciobanu ${ }^{1}$, Ioana Borza ${ }^{1}$, Cristian Domuța ${ }^{1}$, \\ Radu Brejea ', Cornelia Ciobanu', Camelia Bara ${ }^{1}$, Lucian Bara ${ }^{1}$, Adrian Vuşcan ${ }^{1}$, Manuel Gîtea ${ }^{1}$, \\ Ana Pereş ${ }^{1}$, Nandor Köteles ${ }^{1}$ \\ ${ }^{1}$ University of Oradea, Faculty of Environmental Protection, 26 General Magheru St., 410048 Oradea,Romania, e-mail: \\ domuta_cornel@yahoo.com
}

Keywords: melioration crop rotation, de Martonne aridity index, Domuta climate index, irrigation, maize

Summary

\begin{abstract}
The paper is based on the researches carried out in the long term trial placed on the preluvosoil from Oradea in 1976, for establishing the soil water balance. In the irrigated variant the soil moisture was determined 10 to 10 days for maintaining the soil water reserve on irrigation depth $(0-50 \mathrm{~cm}$ for wheat and bean, $0-75 \mathrm{~cm}$ for maize, sunflower, soybean, sugarbeet, potato and alfalfa 1 st year and 0 - 100 $\mathrm{cm}$ for alfalfa 2 nd year) between easily available water content and field capacity. Thus, an average irrigation rate of $2560 \mathrm{~m}^{3} / \mathrm{ha}$ was used in the 9 experimental crops. The average of the annual rainfall for the 1976 - 2008 period was of 625.0 mm. The technologies used were correlated with the needes of the crops, such as melioration crop rotation, chemical fertilizers in accordance with the chemical export on the yield, manure (40 t/ha) was used in potato and sugarbeet. After 33 years of the irrigation use the soil structure degree (38.62\%) did not decrease when compared to the unirrigated maize - wheat crop rotation (37.01\%). Bulk density, total porosity, penetration resistance and hydraulic conductivity have worse values than the ones in the unirrigated variant. The humus content is very close to the humus content determined in 1976, the phosphorus and the potassium content increased very much in comparison with the initial content (117 ppm vs 22.0 ppm); (180.0 ppm vs 102 ppm). The use of the adequate fertilization system and of the irrigation water with a good qaulity did not determine a decrease of the $\mathrm{pH}$ value of the soil. The irrigation determined the improve of the microclimate conditions, the increase of the plant water consumption, yield gains very significant statistically and higher protein content of the maize grains.
\end{abstract}

\section{INTRODUCTION}

Drought and desertification are the major problems of the world in the context of the climate change (Doorembos, Pruitt, 1992, Kay, Angers,1999, Lado, Ben-Hur and Assouline, 2005, Page, Miller and Keeney,1982, Wakindiki, Ben-Hur, 2002) There are climatic changes in Romania, too (Canarache, 1990); Dobrogea and the South-Eastern part are considered the area with desertification; other areas are an important part of Moldavia and the Romanian Plain and a small part of the Western Plain (Domuta, 2005). The Crisurilor Plain is a part of the Western Plain and it was known for its large areas with water logging and drought and also for that the rainfall is not in accordance with the optimum water requirement of the crops. In 1968 the researches regarding the irrigation crop started in Girisu de Cris and in 1976 the researches regarding the crops' water consumption were carried out in Oradea (Domuta, 2003, Grumeza, Kleps, 2005)

The researches regarding the irrigation use in the Crisurilor Plain emphasized the irrigation opportunity in the sustainable agriculture system, the yield gains produced by irrigation were statistically significant every year, the maize, soybean and sugarbeet yields showed improvements in their stability and quality, and the water use efficiency improved, as well. The correlations quantified in the soil-water-plant-atmosphere system (soil moisture-yield, soil moisture - yield gains, water consumption - yield, climate indexes - yield) and economical efficiency sustain the irrigation opportunity in this area (Domuta, 2003, 2005, 2007, 2009, Borza, 2006, Grumeza, Kleps, 2005).

The paper presents the irrigation impact on the main physical and chemical properties of the soil based on a 33 years' study.

\section{MATERIAL AND METHODS}

The researches were carried out in the long term trial placed in 1976 on the preluvosoil from Oradea, in order to study the soil water balance and the crops water consumption. The research data was compared with the data determined in an experiment with whea-maize crop rotations near the research field for water balance study. The crop rotatation used in the research field for the soil water balance study was a melioration one: alfalfa $1^{\text {st }}$ year alfalfa $2^{\text {nd }}$ year - maize - bean - wheat - soybean - sugarbeet - sunflower - potato.

In the ploughed land, the colloid clay content is of $31.5 \%$. 
The field capacity (FC) is a medium one on the soil profile and the wilting point (WP) has a medium value to $80 \mathrm{~cm}$ depth and a high value below this depth. The easily available water content (Wea) was established considering the soil's texture ${ }^{6}$. As a consequence, the following formula was used: Wea $=\mathrm{WP}+2 / 3(\mathrm{FC}-\mathrm{WP})$.

During the research period (1976-2008), on the irrigation depth $(0-50 \mathrm{~cm}$ for wheat and bean; $0-75 \mathrm{~cm}$ for maize, soybean, sunflower, sugarbeet, potato, alfalfa $1^{\text {st }}$ year; $0-75 \mathrm{~cm}$ for alfalfa $2^{\text {nd }}$ year) ten to ten days determinations of the soil moisture permitted to maintain the soil water reserve between the easily available water content and the field capacity. The accomplishment of this objective determined the use of $2.560 \mathrm{~m}^{3} / \mathrm{ha}$ of irrigation water in the studied period and in the studied crops.

The water source for irrigation is ground water at a $15 \mathrm{~m}$ depth. The main chemical properties of the irrigation water used are presented in table 1 . The natrium content $(12.9 \%)$ is low and the salinization potential is low, too $(\mathrm{CSR}=-17 ; \mathrm{SAR}=0.52)$ (table 1$)$.

Table 1

Chemical parametes of the irrigation water used in the research field, Oradea

\begin{tabular}{|l|l|l|l|l|l|l|l|l|l|l|l|c|c|}
\hline $\mathrm{Ca}^{2+}$ & $\mathrm{Mg}^{2+}$ & $\mathrm{Na}^{+}$ & $\mathrm{K}^{-}$ & $\mathrm{CO}_{3}^{2-}$ & $\mathrm{HCO}_{3}$ & $\mathrm{CL}^{-}$ & $\mathrm{SO}_{4}^{2-}$ & $\mathrm{pH}$ & $\begin{array}{c}\mathrm{Na} \\
\%\end{array}$ & $\begin{array}{c}\text { Min. } \\
\text { rezid.fix } \\
\mathrm{g} / \mathrm{l}\end{array}$ & $\mathrm{SAR}$ & $\begin{array}{c}\mathrm{N} . \\
\mathrm{CSR}\end{array}$ & $\begin{array}{c}\text { Florea } \\
\text { Class }\end{array}$ \\
\hline
\end{tabular}

The crop technologies included the use of the chemical fertilizers according to the yield export for every crop and a medium rate on the melioration crop rotation: $\mathrm{N} 140 \mathrm{~kg} / \mathrm{ha} \mathrm{s.a}, \mathrm{P}_{2} \mathrm{O}_{5} 110 \mathrm{~kg} / \mathrm{ha} \mathrm{s.a}$ and $\mathrm{K}_{2} \mathrm{O} 90 \mathrm{~kg} / \mathrm{ha} \mathrm{s.a.} \mathrm{In}$ the sugarbeet and the potato crop a dose of $40 \mathrm{t} / \mathrm{ha}$ of manure was used.

The macrostructure's hydrostability (aggregates $>0.25 \mathrm{~mm}$ ) was determined using the Cseratzki method (Gh. Budoi, A. Penescu, 1996). The bulk density, hydraulic conductivity and the penetration resistance were determined using the same cylinders with a volume of $100 \mathrm{~cm}^{3}$. The humus content, $\mathrm{pH}$, the mobile phosphorus and mobile potassium content were determined using the common methods of the agrochemistry laboratories, in a laboratory of the Agricultural Research and Development Station Oradea.

De Martonne aridity index (IdM) was determined using the formula

$$
\operatorname{IdM}=\frac{12 \mathrm{p}}{t+10} \text { in wich: }
$$

$\mathrm{p}=$ monthly rainfall $(\mathrm{mm}) ; \mathrm{t}=$ average temperature on the month $\left({ }^{\circ} \mathrm{C}\right)$

Characterization class: < 15 arid; 15-24 demiarid; 24-30 moderate drought; 31-35 moderate wet I; 36-40 moderate wet II; 41-50 wet; 51-60 wet I; 61-80 wet II; 81-100 very wet; >100 excessive wet (Domuța, 2009)

Domuța climate index was determined using the formula:

$$
\mathrm{IcD}=\frac{100 \mathrm{~W}+12.9 \mathrm{~A}}{\sum \mathrm{t}+\mathrm{Sb}} \text { in wich: }
$$

$\mathrm{W}=$ water $(\mathrm{mm}) ; \mathrm{A}=$ air humidity $(\%) ; \Sigma \mathrm{t}=$ sum of the monthly average temperature $\left({ }^{\circ} \mathrm{C}\right) ; \mathrm{Sb}=$ sun brilliance.

Characterization class: < 3 excessive drought; 3.1-5 very drought; 5.1-7 droughty; 7.1-9 median droughty; 9.1-12 median wet; 12.1-15 wet I; 51-60 wet I; 15.1-18 wet II; 18.1-25 wet II; >25 excessive wet (Domuța, 2009)

Both de Martonne aridity index and Domuța climate index for irrigated vriant included the irrigation rate in the calculation formula (Domuța C., 2009)

Water consumption was determined using the soil water balance method.

The research data was analysed using the variance analysis method (Domuta, 2009).

\section{RESULTS AND DISCUSSION}

\section{The irrigation influence on the soil physical properties}

\section{The irrigation influence on the soil structure}

The soil aggregates with a diameter bigger than $0.25 \mathrm{~mm}$ from the variant with irrigated melioration crop rotation had a value of $38.62 \%$, higher than the value $(37.01 \%)$ determined in the variant with unirrigated wheatmaize crop rotation but the difference $(1.61 \% ; 4 \%)$ is not statistically assured. In the variant with unirrigated melioration crop rotation, the macro aggregates' hydro stability increased statistically very significant in comparison with the unirrigated wheat-maize and an important difference $(12.58 \% ; 32.6 \%)$ was registered in comparison with the irrigated melioration crop rotation (table 2) 
Irrigation influence (1976-2009) on the macrostructue's hydrostability, in the conditions of the preluvosoil from Oradea

\begin{tabular}{|c|c|c|c|c|c|}
\hline \multirow{2}{*}{ Crop rotation } & \multicolumn{2}{|c|}{$\begin{array}{c}\text { Macrostructure } \\
\text { hydrostability }\end{array}$} & \multicolumn{2}{c|}{ Difference } & \multirow{2}{*}{$\begin{array}{c}\text { Statistical } \\
\text { significance }\end{array}$} \\
\cline { 2 - 5 } & $\%$ & $\%$ & $\%$ & $\%$ & Control \\
\hline 1.Unirrigated wheat-maize crop rotation & 37.01 & 100 & - & - & - \\
\hline 2. Irrigated melioration crop rotation & 38.62 & 104 & 1.61 & 4 & $\mathrm{xxx}$ \\
\hline 3. Unirrigated melioration crop rotation & 51.20 & 138 & 14.19 & 38 & 2.01 \\
\hline LSD 5\% & & & 3.95 \\
LSD 1\% & & & 6.03
\end{tabular}

Analyzing the situation of the macro aggregates for every determined diameter, a very different situation was registered regarding the macro aggregates with a diameter $>5.0 \mathrm{~mm}$; in the variant with unirrigated melioration crop rotation a value $(2.80 \%)$ with $618 \%$ higher than the value $(0.39 \%)$ from the unirrigated wheat-maize crop rotation was determined; the value $(0.62 \%)$ from the irrigated melioration crop rotation is with $39 \%$ higher than the value registered in the unirrigated wheat-maize crop rotation. There were differences regarding the macro aggregates' hydro stability in the $2.0 \mathrm{~mm}, 1.0 \mathrm{~mm}$ and $0.25 \mathrm{~mm}$ case, too (table 3 ).

Macroaggregates diameter ( $\mathrm{mm})$ under the irrigation influence in

Table 3 the conditions of the preluvosoil from Oradea

\begin{tabular}{|l|c|c|c|c|c|c|c|c|}
\hline \multirow{2}{*}{ Crop rotation } & \multicolumn{8}{|c|}{ Macro aggregates diameter } \\
\cline { 2 - 10 } & \multicolumn{2}{|c|}{$>5 \mathrm{~mm}$} & \multicolumn{2}{|c|}{$2.1-5 \mathrm{~mm}$} & $1.1-2.0 \mathrm{~mm}$ & \multicolumn{2}{c|}{$0.25-1.0 \mathrm{~mm}$} \\
\cline { 2 - 10 } & $\%$ & $\%$ & $\%$ & $\%$ & $\%$ & $\%$ & $\%$ & $\%$ \\
\hline 1.Unirrigated wheat-maize crop rotation & 0.39 & 100 & 3.88 & 100 & 3.10 & 100 & 29.64 & 100 \\
\hline 2. Irrigated melioration crop rotation & 0.62 & 139 & 2.88 & 74 & 3.45 & 111 & 31.64 & 107 \\
\hline 3. Unirrigated melioration crop rotation & 2.80 & 718 & 3.90 & 101 & 3.76 & 121 & 40.74 & 137 \\
\hline
\end{tabular}

The irrigation influence on the bulk density and on the total porosity

In the variant with unirrigated wheat-maize crop rotation, the value of the bulk density $\left(1.34 \mathrm{~g} / \mathrm{cm}^{3}\right)$ is high. In the variant with irrigated melioration crop rotation, the value of the bulk density $\left(1.40 \mathrm{~g} / \mathrm{cm}^{3}\right)$ increased statistically significant but is situated in the same characterization class. The value from unirrigated melioration crop rotation $\left(1.20 \mathrm{~g} / \mathrm{cm}^{3}\right)$ is statistically very significant lower than the value registered in the wheat-maize crop rotation emphasizing the importance of the melioration crop rotation in the evolution of the soil's physical properties (table 4).

Table 4

Irrigation influence (1976-2009) on the bulk density of the preluvosoil from Oradea

\begin{tabular}{|c|c|c|c|c|c|}
\hline \multirow{2}{*}{ Crop rotation } & \multicolumn{2}{|c|}{ Bulk density } & \multicolumn{2}{c|}{ Difference } & \multirow{2}{*}{$\begin{array}{c}\text { Statistical } \\
\text { significance }\end{array}$} \\
\cline { 2 - 5 } & $\mathrm{g} / \mathrm{cm}^{3}$ & $\%$ & $\mathrm{~g} / \mathrm{cm}^{3}$ & $\%$ & Control \\
\hline 1.Unirrigated wheat-maize crop rotation & 1.34 & 100 & - & - & $\mathrm{x}$ \\
\hline 2. Irrigated melioration crop rotation & 1.40 & 104.5 & 0.06 & 4.5 & 000 \\
\hline 3. Unirrigated melioration crop rotation & 1.20 & 89.6 & -0.14 & -10.4 & 0.05 \\
\hline LSD 5\% & & & 0.09 \\
LSD 1\% & & & 0.13
\end{tabular}

As a consequence, in comparison with the total porosity $(49.4 \%)$ determine din the unirrigated wheat-maize crop rotation, in the irrigated melioration crop rotation a smaller value was determined (47.1\%) but the values are situated in the same characterization class. The value of the total porosity $(54.7 \%)$ in the unirrigated melioration crop rotation is statistically very significant, higher than the one registered in the unirrigated wheatmaize crop rotation (table 5). 
Irrigation influence (1976-2009) on the total porosity of the preluvosoil from Oradea

\begin{tabular}{|c|c|c|c|c|c|}
\hline \multirow{2}{*}{ Crop rotation } & \multicolumn{2}{|c|}{ Total porosity } & \multicolumn{2}{|c|}{ Difference } & \multirow{2}{*}{$\begin{array}{c}\text { Statistical } \\
\text { significance }\end{array}$} \\
\cline { 2 - 5 } & $\%$ & $\%$ & $\%$ & $\%$ & Control \\
\hline 1.Unirrigated wheat-maize crop rotation & 49.4 & 100 & - & - & 0 \\
\hline 2. Irrigated melioration crop rotation & 47.1 & 95.4 & -2.3 & -4.6 & xxx \\
\hline 3. Unirrigated melioration crop rotation & 54.7 & 110.8 & 5.3 & 10.8 & 0.9 \\
LSD 5\% & & & & 2.6 \\
LSD 1\% & & & & 4.9
\end{tabular}

The irrigation influence on the penetration resistance

In the irrigated melioration crop rotation the value of the penetration resistance $\left(31.38 \mathrm{~kg} / \mathrm{cm}^{2}\right)$ is statistically significant higher than the value $\left(29.3 \mathrm{~kg} / \mathrm{cm}^{2}\right)$ determined in the unirrigated wheat-maize crop rotation but the values are situated in the same characterization class, a median one. In unirrigated conditions, the melioration crop rotation determined a decrease of the penetration resistance with $32.7 \%$ statistically very significant. The characterization class changes to "small", in this case (table 6).

Table 6

Irrigation influence (1976-2009) on the penetration resistance of the preluvosoil from Oradea

\begin{tabular}{|c|c|c|c|c|c|}
\hline \multirow{2}{*}{ Crop rotation } & \multicolumn{2}{|c|}{ Penetration resistance } & \multicolumn{2}{|c|}{ Difference } & \multirow{2}{*}{$\begin{array}{c}\text { Statistical } \\
\text { significance }\end{array}$} \\
\hline & $\mathrm{kg} / \mathrm{cm}^{2}$ & $\%$ & $\mathrm{~kg} / \mathrm{cm}^{2}$ & $\%$ & \\
\hline 1.Unirrigated wheat-maize crop rotation & 29.3 & 100 & - & - & Control \\
\hline 2. Irrigated melioration crop rotation & 31.38 & 107.1 & 0.8 & 7.1 & $\mathrm{x}$ \\
\hline 3. Unirrigated melioration crop rotation & 19.71 & 67.3 & -3.7 & -32.7 & 000 \\
\hline LSD 5\% & & & & & 0.6 \\
\hline LSD $1 \%$ & & & & & 1.4 \\
\hline LSD $0.1 \%$ & & & & & 3.5 \\
\hline
\end{tabular}

The irrigation influence on the hydraulic conductivity

Irrigation did not have a statistically significant influence, the value of the hydraulic conductivity registered in the melioration crop rotation, $13.5 \mathrm{~mm} / \mathrm{h}$, is very close to the value registered in the wheat-maize crop rotation $(14.0 \mathrm{~mm} / \mathrm{h})$. In the unirrigated melioration crop rotation, the hydraulic conductivity $(20.6 \mathrm{~mm} / \mathrm{h})$ is statistically very significant higher than the value determined in the unirrigated wheat-maize crop rotation (table 7).

Table 7

Irrigation influence (1976-2009) on the hydraulic conductivity of the preluvosoil from Oradea

\begin{tabular}{|c|c|c|c|c|c|}
\hline \multirow{2}{*}{ Crop rotation } & \multicolumn{2}{|c|}{ Hydraulic conductivity } & \multicolumn{2}{|c|}{ Difference } & \multirow{2}{*}{$\begin{array}{c}\text { Statistical } \\
\text { significance }\end{array}$} \\
\hline & $\mathrm{mm} / \mathrm{h}$ & $\%$ & $\mathrm{~mm} / \mathrm{h}$ & $\%$ & \\
\hline 1.Unirrigated wheat-maize crop rotation & 14.0 & 100 & - & - & Control \\
\hline 2. Irrigated melioration crop rotation & 13.5 & 96.5 & -0.5 & -3.5 & - \\
\hline 3. Unirrigated melioration crop rotation & 20.6 & 147.2 & 6.6 & 47.2 & $\mathrm{xxx}$ \\
\hline \multicolumn{5}{|l|}{ LSD 5\% } & 1.7 \\
\hline \multicolumn{5}{|l|}{ LSD $1 \%$} & 3.1 \\
\hline \multicolumn{5}{|l|}{ LSD $0.1 \%$} & 5.6 \\
\hline
\end{tabular}

The irrigation influence on the soil chemical properties

The irrigation influence on the humus content

In the melioration crop rotation conditions and good soil management practices in comparison with the humus content $(1.7 \%)$ in the start year of the researches, a very close value $(1.8 \%)$ was registered in the irrigated variant in 2008. In unirrigated conditions the melioration crop rotation and the applied soil management determined the increase of the humus content $(1.9 \%)$ in comparison with the start year; the difference $(11.8 \%)$ is distinctively significant (table 8). 
Irrigation influence (1976-2009) on the humus content of the preluvosoil from Oradea

\begin{tabular}{|c|c|c|c|c|c|}
\hline \multirow{2}{*}{ Specification } & \multicolumn{2}{|c|}{ Humus } & \multicolumn{2}{c|}{ Difference } & \multirow{2}{*}{$\begin{array}{c}\text { Statistical } \\
\text { significance }\end{array}$} \\
\cline { 2 - 5 } & $\%$ & $\%$ & $\%$ & - & Control \\
\hline 1. In 1976 & 1.70 & 100 & - & -1.7 & - \\
\hline 2. In 2008 (irrigated) & 1.67 & 98.3 & -0.03 & 11.8 & xx \\
\hline 3. In 2008(unirrigated) & 1.90 & 111.8 & 0.20 & & 0.07 \\
LSD 5\% & & & 0.12 \\
LSD 1\% & & & 0.21
\end{tabular}

\section{The irrigation influence on the $\mathrm{pH}$ value}

In 2008, the soil reaction ( $\mathrm{pH}=6.0)$ in the irrigated variant increased, distinctively significant, in comparison with the value of the soil reaction $(\mathrm{pH}=5.81)$ determined in the start year of the experiment. The explanation consists of the $\mathrm{Ca}^{2+}$ high content of the irrigation water used in the research field. In unirrigated variant the $\mathrm{pH}$ value (5.58) decreased, distinctively significant due to the chemical fertilizers use (table 9).

Irrigation influence (1976-2009) on the $\mathrm{pH}$ values of the preluvosoil from Oradea

Table 9

\begin{tabular}{|c|c|c|c|c|c|}
\hline \multirow{2}{*}{ Specification } & \multicolumn{2}{|c|}{$\mathrm{pH}$} & \multicolumn{2}{c|}{ Difference } & \multirow{2}{*}{$\begin{array}{c}\text { Statistical } \\
\text { significance }\end{array}$} \\
\cline { 2 - 5 } & Value & $\%$ & Value & $\%$ & Control \\
\hline 1. In 1976 & 5.81 & 100 & - & - & $\mathrm{xx}$ \\
\hline 2. In 2008 (irrigated) & 6.00 & 103.3 & 0.29 & 3.3 & 00 \\
\hline 3. In 2008(unirrigated) & 5.58 & 96.1 & -0.23 & -3.9 & 0.11 \\
LSD 5\% & & & & 0.17 \\
LSD 1\% & & & & 0.31 \\
LSD 0.1\%
\end{tabular}

The irrigation influence on the mobile phosphorum and potassium

The mobile phosphorus content of the preluvosoil from the research field in the start year, $22.0 \mathrm{ppm}$ was low, but after 33 years of good agriculture practices - melioration crop rotation with alfalfa, chemical fertilizers doses in accordance with the yield export - the mobile phosphorus content became very good, $117.0 \mathrm{ppm}$ in unirrigated conditions and $109.0 \mathrm{ppm}$ in irrigated conditions; the differences in comparison with the start year are statistically very significant both in unirrigated and irrigated conditions (table 10).

Table 10

Irrigation influence (1976-2009) on mobile phosphorus content of the preluvosoil from Oradea

\begin{tabular}{|c|c|c|c|c|c|}
\hline \multirow{2}{*}{ Specification } & \multicolumn{2}{|c|}{$\mathrm{P}_{\mathrm{AL}}$} & \multicolumn{2}{c|}{ Difference } & \multirow{2}{*}{$\begin{array}{c}\text { Statistical } \\
\text { significance }\end{array}$} \\
\cline { 2 - 5 } & $\mathrm{ppm}$ & $\%$ & $\mathrm{ppm}$ & - & Control \\
\hline 1. In 1976 & 22.0 & 100 & - & 395.5 & $\mathrm{xxx}$ \\
\hline 2. In 2008 (irrigated) & 109.0 & 495.5 & 87.0 & 431.9 & $\mathrm{xxx}$ \\
\hline 3. In 2008(unirrigated) & 117.0 & 531.9 & 95.0 & & 21 \\
LSD 5\% & & & 39 \\
LSD 1\% & & & \\
LSD 0.1\%
\end{tabular}

The mobile potassium content of the preluvosoil in the start year (183.0 ppm) was high and, after 33 years, the mobile potassium content was very high, $290.0 \mathrm{ppm}$ in unirrigated conditions and $240.0 \mathrm{ppm}$ in irrigated conditions; the differences in comparison with the start year are statistically very significant (table 11). 
Irrigation influence (1976-2009) on mobile potassium content of the preluvosoil from Oradea

\begin{tabular}{|c|c|c|c|c|c|}
\hline \multirow{2}{*}{ Specification } & \multicolumn{2}{|c|}{$\mathrm{K}_{\mathrm{AL}}$} & \multicolumn{2}{c|}{ Difference } & \multirow{2}{*}{$\begin{array}{c}\text { Statistical } \\
\text { significance }\end{array}$} \\
\cline { 2 - 5 } & $\mathrm{ppm}$ & $\%$ & $\mathrm{ppm}$ & $\%$ & Control \\
\hline 1. In 1976 & 183.0 & 100 & - & - & $\mathrm{xxx}$ \\
\hline 2. In 2008 (irrigated) & 240.0 & 131.2 & 57 & 31.2 & $\mathrm{xxx}$ \\
\hline 3. In 2008(unirrigated) & 290.0 & 158.5 & 107 & 58.5 & 12 \\
\hline LSD 5\% & & & 30 \\
LSD 1\% & & & \\
LSD 0.1\%
\end{tabular}

The irrigation influence on the microclimate conditions

The irrigation determined the improve of report between water and temperature quantified by de Martonne aridity index with $126 \%$; the microclimate was characterized "wet" in comparison with "demiarid", the microclimate of the unirrigated maize. The use of the Domuța climate index show a "wet I" microclimate in comparison with "median drought" the microclimate of the unirrigated maize. (table 12)

Table 12

Irrigation influence on microclimate in maize, Oradea 2007-2009

\begin{tabular}{|l|c|c|c|}
\hline \multirow{2}{*}{ Variant } & \multicolumn{3}{c|}{ Irrigation season (April-August) } \\
\cline { 2 - 4 } & Value & $\%$ & Microclimate characterisation \\
\hline \multicolumn{4}{|c|}{ de Martonne aridity index (IdM) } \\
\hline Unirrigated & 21.7 & 100 & demiarid \\
\hline Irrigated & 49.1 & 226 & wet \\
\hline \multicolumn{4}{|c|}{ Domuța climate index (IcD) } \\
\hline Unirrigated & 7.0 & 100 & median drought \\
\hline Irrigated & 14.5 & 207 & wet I \\
\hline
\end{tabular}

The irrigation influence on the plants water consumption

Total water consumption of the maize plants increased with $45.1 \%$ in irrigated conditions, variation interval $9-145 \%$. The participation percentage of the irrigation in covering of the total water consumption across the yeas was between $7.4 \%$ and $61.2 \%$ (table 13 ).

Table 13

Irrigation influence on maize water consumption, Oradea 1976-2009

\begin{tabular}{|l|c|c|c|c|c|c|}
\hline \multirow{3}{*}{ Variant } & \multicolumn{2}{|c|}{ Total water consumption } & \multicolumn{4}{|c|}{ Covering sources } \\
\cline { 2 - 7 } & $\mathrm{m}^{3} / \mathrm{ha}$ & $\begin{array}{c}\text { Variation interval } \\
\%\end{array}$ & $\begin{array}{c}\text { Soil water } \\
\text { reserve }\end{array}$ & Rainfall & $\mathrm{m}^{3} / \mathrm{ha}$ & Variation interval \% \\
\hline Unirrigated & 4343 & 100 & 1064 & 3279 & - & - \\
\hline Irrigated & 6300 & $109-245$ & 536 & 3279 & 2452 & $7.4-61.2$ \\
\hline
\end{tabular}

The irrigation influence on the maize yield quantity and quality

The irrigation determined an yield gains of $78 \%$, variation interval $7-812 \%$. The yield stability was improved, too; the standard deviation value decreased with $42.6 \%$ (table 14)

The protein content of the maize grains increased in the irrigated variant in comparison with unirrigated variant with $19.7 \%$. As consequence, the relative difference between the protein production from irrigated varint and protein production from unirrigated variant (115\%) is bigger than relative difference between grosss production $(78 \%)$ (table 15$)$.

Table 14

Irrigation influence on maize yield, Oradea 1976-2009

\begin{tabular}{|c|c|c|c|c|c|c|}
\hline \multirow{3}{*}{ Variant } & \multicolumn{4}{|c|}{ Yield } & \multirow{2}{*}{\multicolumn{2}{|c|}{ Standard deviation }} \\
\hline & \multicolumn{2}{|c|}{ Average } & \multicolumn{2}{|c|}{ Variation interval } & & \\
\hline & $\mathrm{Kg} / \mathrm{ha}$ & $\%$ & $\mathrm{Kg} / \mathrm{ha}$ & $\%$ & $\mathrm{Kg} / \mathrm{ha}$ & $\%$ \\
\hline Unirrigated & 6870 & 100 & $1510-11840$ & 100 & 3271 & 100 \\
\hline Irrigated & 12232 & 178 & $7850-16480$ & $107-912$ & 1879 & 57.4 \\
\hline
\end{tabular}

$\operatorname{LSD}_{5 \%}=370 ; \operatorname{LSD}_{1 \%}=490 ; \operatorname{LSD}_{0.1} \%=720$ 
Irrigation influence on the grains protein content of the maize, Oradea 2007-2009

\begin{tabular}{|l|c|c|c|c|}
\hline \multirow{2}{*}{ Variant } & \multicolumn{4}{|c|}{ Protein content } \\
\cline { 2 - 5 } & $\%$ & $\%$ & $\mathrm{Kg} / \mathrm{ha}$ & 100 \\
\hline Unirrigated & 8.88 & 100 & 605.0 & 215 \\
\hline Irrigated & 10.63 & 119.7 & 1300.3 & $\%$ \\
\hline
\end{tabular}

\section{CONCLUSIONS}

The researches that were carried out in the long term trial placed on the preluvosoil from Oradea, in 1976, in the Northern-Western part of Romania, led to the following conclusions:

- In the melioration crop rotation with alfalfa, after 33 years of a correct irrigation use, the macro aggregates' hydro stability degree $(38.62 \%)$ did not decrease in comparison with the unirrigated wheat-maize crop rotation. In unirrigated conditions, the value $(51.2 \%)$ determined in the melioration crop is very significant, higher than the value determined in the wheat-maize crop rotation; the highest differences were registered in the aggregates with a diameter bigger than $5 \mathrm{~mm}$.

- In the irrigated melioration crop rotation, the bulk density, total porosity, penetration resistance and the hydraulic conductivity had worse values than the ones in the unirrigated wheat-maize crop rotation. In the unirrigated melioration crop rotation, the values were very significant better than the values from unirrigated wheat-maize.

- After 33 years of a correct irrigation use and in the conditions of the melioration crop rotation and organic and chemical fertilization in accordance with the yield export, the humus content did not decrease significant in comparison with the initial content $1.67 \%$ vs. $1.4 \%$; in the unirrigated variant the difference is statistically very significant bigger than the initial content.

- The use of the irrigation water with a $\mathrm{Ca}^{2+}$ high content determined an increase of the $\mathrm{pH}$ value distinctively significant (6.0 vs. 5.81) in comparison with the initial pH. In the unirrigated variant, the chemical fertilizers use determined a decrease distinctively significant (5.5 vs. 5.81) of the $\mathrm{pH}$ in comparison with the initial value.

- The mobile phosphorus increased in comparison with the initial value $(22.0 \mathrm{ppm})$ with $39.5 \%$ in the irrigated variant and with $431.9 \%$ in the unirrigated variant. The increase of the mobile potassium was of $31.2 \%$ and $58.5 \%$. All the differences in comparison with the initial values are statistically very significant.

The irrigation determined the improve of the microclimate conditions, the increase of the plants water conditions, the yield gains very significant statistically and bigger protein content of the maize.

\section{REFERENCES}

1. Budoi Gh., A. Penescu, Soil management. Ceres Publishing House Bucharest, 1996, pp. 130-180.

2. Canarache A, The physics of the agricultural soils. Ceres Publishing House Bucharest, 1990, pp. 20-90.

3. Domuta C., The irrigation opportunity in the Crisurilor Plane. University of Oradea Publishing House, 2003, pp. 7-45

4. Domuta C., Crop irrigation. University of Oradea Publishing House, 2005, pp.170-230.

5. Domuta C., Experimental technique. University of Oradea Publishing House, 2006, pp. 15-60

6. Domuta C., Crop rotation in the Crisurilor Plane. University of Oradea Publishing House, 2007, pp. 15-80.

7. Doorembos,J. W.O. Pruitt, Crop water requirements. FAO Irrigation and Drainage Paper no.24, 1992, FAO Rome, Italy, pp. $120-170$.

8. Grumeza N., Cr. Kleps, Irrigation works in Romania. Ceres Publishing House, Bucharest, 2005, pp.170-213

9. Kay B.P., D.A. Angers, Soil structure. Handbook of Soil Sciences. CRC Press New York, , 1999, pp. $23-47$.

10. Lado M., M. Ben-Hur And S. Assouline, Effects of Effluent Irrigation on Seal Formation, Infiltration, and Soil Loss during Rainfall. Published in Soil Science Society Agronomy Journal 69, 2005, pp.1432-1439.

11. Page A.L., R.H. Miller And D.R. Keeney: Methods of Soil Analysis, Part 2- Chemical and Microbiological Properties, Second Edition. American Society of Agronomy,Inc,SSSA,1982, pp.17-50

12. Wakindiki I.I., M. Ben-Hur, Soil mineralogy and texture effects on structural crust formation, 17th World Congress of Soil Science, Bangkok, Thailand, 14-20 August, 2002. 